\title{
Policy alienation of public professionals: A comparative case study of insurance physicians and secondary school teachers
}

Lars Tummers, Victor Bekkers, Bram Steijn

Tummers, L.G., Bekkers, V.J.J.M. \& Steijn, A.J. (2012). Policy alienation of public professionals: A comparative case study of insurance physicians and secondary school teachers. International Journal of Public Administration, 35(4), 259-271.

Department of Public Administration

Erasmus University Rotterdam

P.O. Box 1738

NL-3000 DR Rotterdam

Tummers@fsw.eur.nl

Bekkers@fsw.eur.nl

Steijn@fsw.eur.nl 


\begin{abstract}
Currently, there is an intense debate on the pressures facing public professionals in service delivery. Several studies show increasing discontent among professionals toward policies they have to implement. In this article, we aim to contribute to this topic by analyzing this discontent of public professionals in terms of 'policy alienation'. The policy alienation concept is used to frame the experiences of professionals in a coherent theoretical framework. We have used a qualitative comparative case study of Dutch insurance physicians and secondary school teachers to study the factors that influence the degree of policy alienation across different domains. Our article shows that facets of New Public Management are important in explaining the pressures on public professionals implementing public policies. However, others factors are also prominent, and the degree of the implementers' professionalism seems especially important. These insights help in understanding why public professionals embrace or resist the implementation of public policies.
\end{abstract}

\title{
Key words
}

1. Public professionals

2. Policy implementation

3. Policy alienation

4. Neoliberalism

5. Professionalism 


\section{Introduction}

Currently, there is an intense debate concerning professionals in the public sector (Ackroyd et al., 2007; Currie et al., 2009; Emery \& Giauque, 2003; Hebson et al., 2003). Authors such as Duyvendak (2006) and Freidson (2001) note that many of the pressures that professionals face are related to the difficulties they have with the policies they have to implement. For example, Bottery (1998:40), examining the pressures on professionals stemming from new policies in education and healthcare in Great Britain, cites a teacher arguing that: 'The changes have been outrageous, and have produced a culture of meritocracy and high flyers. There's massive paperwork because the politicians don't believe teachers are to be trusted.' A second example refers to the introduction of a new reimbursement policy (known as Diagnosis Treatment Combinations) in mental healthcare in the Netherlands. In one large-scale survey, as many as nine out of ten professionals wanted to abandon this new policy (Palm et al., 2008:11). Psychologists even went as far as to openly demonstrate on the street against this policy. A major reason for this was that many could not align their professional values with the content of the policy. Overall, several studies show an increasing discontent among public professionals toward public policies (see also Hebson et al., 2003; Pratchett \& Wingfield, 1996).

In this article, we want to contribute to this important topic. Our main goal is to identify those factors which determine the experiences of public professionals with the policies they have to implement. This is achieved using a qualitative comparative case study, which allows us to study whether the factors that influence the degree of policy alienation are similar across different public domains. This is theoretically relevant as it contributes to the debate on pressured professionals. Indeed, although scholars such as Exworthy and Halford (1998, see also Noordegraaf, 2007) note that there are a number of factors creating professional pressures, this has yet to be examined thoroughly on the level of actual policy implementation. We analyze this using two qualitative case studies, looking in detail at national, organizational, and policy factors.

We will analyze the relevance of these factors for professional pressure using the policy alienation framework. Policy alienation can be defined as a general cognitive state of psychological disconnection from the policy program being implemented, here by a public professional who regularly interacts directly with clients (Tummers et al., 2009). The policy alienation concept consists of five dimensions: strategic powerlessness, tactical powerlessness, operational powerlessness, societal meaninglessness, and client meaninglessness. In this way, the policy alienation concept adds to the literature by framing the experiences of public professionals with new policies in a coherent theoretical framework. Indeed, although some prominent policy implementation scholars have 
emphasized the important role of implementers identifying with the policy (Ewalt \& Jennings, 2004; May \& Winter, 2009; Van Meter \& Van Horn, 1975), few have developed and applied a framework for analyzing this topic (O'Toole, 2000). Furthermore, although change management scholars have a long history of studying the role of willingness (or resistance) to a change (Judson, 1991; Lewin, 1951), little attention has been given to the way in which public employees react to new public policies, or the particularities in this context (Kickert, 2010). Concluding, this study is innovative in that, using a coherent theoretical framework, it comparatively analyses the factors influencing the experiences of public professionals with the policies they have to implement.

Studying the policy alienation of public professionals and the associated factors is not only of academic interest, it is also highly relevant for policymakers. Firstly, because, when implementers are unable to identify with a policy, this can negatively influence policy effectiveness and thereby organizational performance (Ewalt \& Jennings, 2004; May \& Winter, 2009). Secondly, a high degree of policy alienation can also affect the quality of interactions between professionals and citizens, which may eventually influence the output legitimacy of government (Bekkers et al., 2007). A better understanding of policy alienation and its determining factors in different contexts is important for policymakers if they want to develop policies which will be more readily accepted by implementing public professionals. We analyze the complex set of factors that influence the experiences of public professionals with policies, and derive a number of important factors. For instance, policymakers and managers can use the insights to consider what opportunities are open to them for increasing the commitment (or lowering the alienation) of public professionals implementing policies.

This brings us to the outline of this article. Section 2 conceptualizes policy alienation and examines factors that possibly influence its degree. Section 3 outlines the method and the results of the empirical analyses. In Section 4, we draw some conclusions by discussing the contribution of this article to the debate on public professionals and professionalism in the public sector.

\section{A theoretical framework of policy alienation}

This section firstly provides the background for the study on policy implementation by professionals by examining neoliberal reforms and their effects on professionals. We will then define the dimensions of policy alienation. Finally, we will examine a number of factors that will possibly influence these dimensions. 


\subsection{Neo-liberalism, NPM, and the impact on professionals}

The economic crises in the 1970s and 1980s and the collapse of the Communist bloc at the end of the 1980s, fuelled political opposition to state interventionism in favor of free market reform. As a result, there was a rise of neoliberalism in a number of countries (Clarke \& Newman, 1997; Harvey, 2007). For instance, in the United Kingdom, Margaret Thatcher emphasized freer markets and less state intervention. She aimed to decrease government interference in the economy, including by privatizing nationally-owned enterprises.

Neoliberalism can briefly be described as 'the idea that the market offers the best solutions to social problems and that governments' attempted solutions, in contrast, are inefficient and antithetical to the value of freedom' (Holland et al., 2007: xi). The proponents of neoliberalism spearheaded programs for the modernization of government, such as denationalization, disaggregation of public-sector units, and more explicit performance measures (Le Grand, 2007). In these ways, the doctrine of neoliberalism led to a number of reforms under the label 'New Public Management' (Hood, 1991; Pollitt \& Bouckaert, 2004).

The rise of neoliberalism has had profound impacts on professionals working in the public sector (Noordegraaf, 2007). Neoliberalism, and its resulting policies, focus on business-like values, such as efficiency, transparency, and client choice. These values can dominate traditional professional values such as autonomy and equity. Next, the emphasis on the market and the individual can erode professional associations, which are used to organize knowledge creation and transfer (Freidson, 2001; Roberts, 2006). This challenges the expert-status of professionals, thereby weakening their power. Moreover, the intense use of performance indicators and audits requires professionals to significantly alter their behavior (Ball, 2003; Power, 1997). Examining education reforms introducing performance indicators and targets, Ball (2003:215) notes that 'the novelty of this epidemic of reform is that it does not simply change what people, as educators, scholars and researchers do, it changes who they are'. In more general terms, Marquand (2004:110) argues that 'in virtually every institution, eighteen years of neoliberalism exalted managers, often recruited from the corporate sector, at the expense of the professionals who formed the backbone of the institution concerned'. However, it would be unwarranted to claim that neoliberalism is viewed as negative for all professions under all circumstances. For instance, Noordegraaf (2007:763) notes that 'these very same evidence-based and outcome-oriented movements are also used to professionalize quasi-, proto- or semi- professional occupations, such as social work and nursing'. However, we can confidently conclude that neoliberalism seem to strongly affect professionals and professional work. 


\subsection{Organizational performance and policy implementation}

One of the results of the focus on neoliberalism and NPM is that the performance of public organizations, and its measurement, has become increasingly important. For instance, Hood (1991:4) notes that one of the doctrinal components of NPM is 'explicit standards and measures of performance' and that 'resource allocation and rewards [are] linked to measured performance'. The organizational performance literature has examined a range of performance measures, such as profitability, market share, and customer satisfaction (Cameron, 1978; Chakravarthy, 1986). With the insight that there is no single ultimate performance indicator, but rather a need to balance a number of indicators, Kaplan and Norton (1992, following Schneiderman) developed the Business Balanced Scorecard. More recent works continue to stress the different components of organizational performance, and methods to measure them (Neely, 2008).

In public organizations, a number of indicators are used to measure performance. For public organizations on the frontline of public service, a major component of organizational performance is the effectiveness and efficiency with which they deliver public policies (Hill \& Hupe, 2009). Policy implementation scholars note that implementers identifying with the policy is essential for policy effectiveness. For instance, Van Meter and Van Horn (1975:482; see also Ewalt \& Jennings, 2004; May \& Winter, 2009) note that:

'Implementation may fail because implementers refuse to do what they are supposed to do. Dispositional conflicts occur because subordinates reject the goals of their superiors ... for numerous reasons: they offend implementers' personal values or self-interest; or they alter features of the organization and its procedures that implementers desire to maintain.'

This brings us to the policy alienation framework used in this article that builds on policy implementation research by emphasizing the crucial role of implementers in achieving policy effectiveness, and thereby organizational performance. Our main assumption is that, the greater the policy alienation of professionals, the lower the policy effectiveness. This is rooted in the notion of policy implementation scholars that implementers identifying with the policy is essential for policy effectiveness (Van Meter \& Van Horn, 1975; Ewalt \& Jennings, 2004; May \& Winter, 2009). Policy alienation is a multidimensional concept, made up of two main dimensions: powerlessness and meaninglessness (for a more elaborate explanation, see Tummers, 2009). In essence, powerlessness is a person's lack of control over events in their life. Meaninglessness, on the other hand, is the inability to comprehend the relationship of one's contribution with a larger purpose. Professionals can feel powerless while implementing a policy, for example if they have no influence over the type, quantity, and quality of the sanctions and rewards they dispense (Lipsky, 1980). Further, it is also evident 
that professionals can feel that implementing a policy is meaningless if, for example, it fails to deliver any apparent benefits for society (Van Thiel \& Leeuw, 2002). In making the dimensions more specific to the situation being studied, we distinguish between strategic, tactical, and operational powerlessness, and between societal and client meaninglessness. The definitions of these dimensions are provided in Table 1.

Table 1 Operationalization of policy alienation: five dimensions

\begin{tabular}{|c|c|c|}
\hline Dimension & Definition & $\begin{array}{l}\text { An example situation leading to a high } \\
\text { score }\end{array}$ \\
\hline $\begin{array}{l}\text { Strategic } \\
\text { powerless- } \\
\text { ness }\end{array}$ & $\begin{array}{l}\text { The perceived influence of the } \\
\text { professionals on decisions concerning } \\
\text { the content of the policy, as is } \\
\text { captured in rules and regulations. }\end{array}$ & $\begin{array}{l}\text { A professional feeling that the policy is } \\
\text { drafted without the help of } \\
\text { implementing professionals or } \\
\text { professional associations. }\end{array}$ \\
\hline $\begin{array}{l}\text { Tactical } \\
\text { powerless- } \\
\text { ness }\end{array}$ & $\begin{array}{l}\text { The professionals' perceived influence } \\
\text { on decisions concerning the way } \\
\text { policy is implemented within their own } \\
\text { organization. }\end{array}$ & $\begin{array}{l}\text { Professionals stating that the } \\
\text { managers in the organization did not } \\
\text { consult them or their colleagues when } \\
\text { designing the implementation process } \\
\text { for the policy. }\end{array}$ \\
\hline $\begin{array}{l}\text { Operational } \\
\text { powerless- } \\
\text { ness }\end{array}$ & $\begin{array}{l}\text { The perceived degree of freedom in } \\
\text { making choices concerning the sort, } \\
\text { quantity, and quality of sanctions and } \\
\text { rewards on offer when implementing } \\
\text { the policy. }\end{array}$ & $\begin{array}{l}\text { Answering 'fully agree' to a survey } \\
\text { question on whether the professional } \\
\text { feels that their autonomy during the } \\
\text { implementation process was lower } \\
\text { than it should be. }\end{array}$ \\
\hline $\begin{array}{l}\text { Societal } \\
\text { meaning- } \\
\text { lessness }\end{array}$ & $\begin{array}{l}\text { The perception of professionals } \\
\text { concerning the added value of the } \\
\text { policy to socially relevant goals. }\end{array}$ & $\begin{array}{l}\text { Stating in an interview that 'I agree } \\
\text { with the policy goal of enhancing } \\
\text { transparency, but I do not see how this } \\
\text { policy helps in achieving this goal.' }\end{array}$ \\
\hline $\begin{array}{l}\text { Client } \\
\text { meaning- } \\
\text { lessness }\end{array}$ & $\begin{array}{l}\text { The professionals' perceptions of the } \\
\text { added value of them implementing a } \\
\text { policy for their own clients. }\end{array}$ & $\begin{array}{l}\text { A professional noting that a particular } \\
\text { policy seriously impinges on their } \\
\text { clients' privacy. }\end{array}$ \\
\hline
\end{tabular}




\subsection{Factors influencing policy alienation}

Policy alienation will be influenced by several factors and, based on public administration literature, the influence of New Public Management and the degree of professionalism of the profession under study seem particularly relevant.

\section{New Public Management}

As a consequence of neoliberal doctrines, New Public Management (NPM) has become prevalent in the public sector (Pollitt \& Bouckaert, 2004). NPM can be seen as encompassing a broad set of management approaches and techniques, borrowed from the private sector, and now applied in the public sector. Hood and Peters (2004:268) commented that NPM is a rather loose term with no two authors listing exactly the same features. Nevertheless, we will use the widely cited overview developed by Hood (1991) to discern various components of NPM:

\section{Table 2 NPM components (Hood, 1991:4-5)}

\begin{tabular}{l|l}
\hline No. & Component \\
\hline 1 & 'Hands-on professional management' in the public sector \\
2 & Explicit standards and measures of performance \\
3 & Greater emphasis on output controls \\
4 & Shift to disaggregation of units in the public sector \\
5 & Shift to greater competition in the public sector \\
6 & Stress on private-sector styles of management practice \\
7 & Stress on greater discipline and parsimony in resource use \\
\hline
\end{tabular}

In our view, two of these NPM components are especially important in explaining the degree of policy alienation: the use of explicit standards and measures of performance (Component 2), referred to as 'performance management' from here on; and the greater emphasis on output controls (Component 3 ).

As noted in the discussion on neoliberalism, a focus on output controls often requires public agencies, managers, and employees to relate their work to performance targets (usually quantitative). Pollitt (2003:46) argues that this kind of performance management can 'lead to over-concentration on what is precisely quantifiable (for example costs, number of licenses issued) and an under-concentration on other aspects which are not so easily measured'. These quantifiable targets tend to focus on efficiency and results, which can then take precedence over values such as equity and security. Public professionals may have difficulty in accepting this changing trade-off in values that becomes manifest when 
implementing a policy program (Hood, 1991; Pollitt, 2003). As such, we would expect public professionals to experience greater societal meaninglessness when performance management and output controls are used when implementing policy (see also Tummers et al., 2009).

Further, these two NPM components can also limit professional discretion, the reverse of operational powerlessness. Extensive performance management and output controls often involve strict internal instructions and will push managers to increase the pressure on staff in order to produce results. We expect such developments to make it harder for professionals to use their discretion. To summarize, we expect that public professionals will experience greater policy alienation when performance management and output controls are employed in implementing a policy.

\section{Degree of professionalism}

Besides the introduced elements of New Public Management, we also expect the degree of professionalism to influence policy alienation. Here, we follow Eraut (1994) and treat professionalism as an ideology, without attempting to distinguish 'true' professions from other contenders.

An important indicator of high professionalism is the existence of a strong professional association (Eraut, 1994). We would expect that such a body might influence the degree of policy alienation experienced by its members. Indeed, in the literature, the relationships that develop between professional associations and governments are considered crucial to the policymaking process as these professional associations can legitimize change by hosting a process of discourse through which change is debated and endorsed (Greenwood et al., 2002).

We can relate this to the policy implementation process. The relationship between 'government' and professional associations is based on a principle of reciprocal return. Governments, for example, can ill-afford to develop policies that will be met with criticism from professionals and so, when professional associations are sufficiently powerful, they can significantly influence policies. However, if professional associations are not considered crucial for the implementation process, they might be bypassed by policy developers. As a result, on a strategic level, professionals might feel powerless and will therefore be alienated from the policy. Based on this argument, we anticipate that, the stronger the professional association, the less strategic powerlessness will be experienced by the implementing professionals.

The status of the professional group can be considered as another indicator of professionalism. We expect that professions with a relatively low status - such as school teachers and social workers - will have greater difficulty in retaining discretion when 
implementing a policy. Related to this, Bucher and Stelling (1969:4) argue that 'the reward [for professional status] is autonomy and influence: the group is accorded the competence to define problems, determine solutions and monitor the functioning of the system'. Thus, overall, we would expect public professionals to experience less policy alienation when (a) professional associations are stronger and/or (b) their profession has a higher status.

Based on the above exploration, we have developed the theoretical framework on policy alienation and its factors shown in Figure 1.

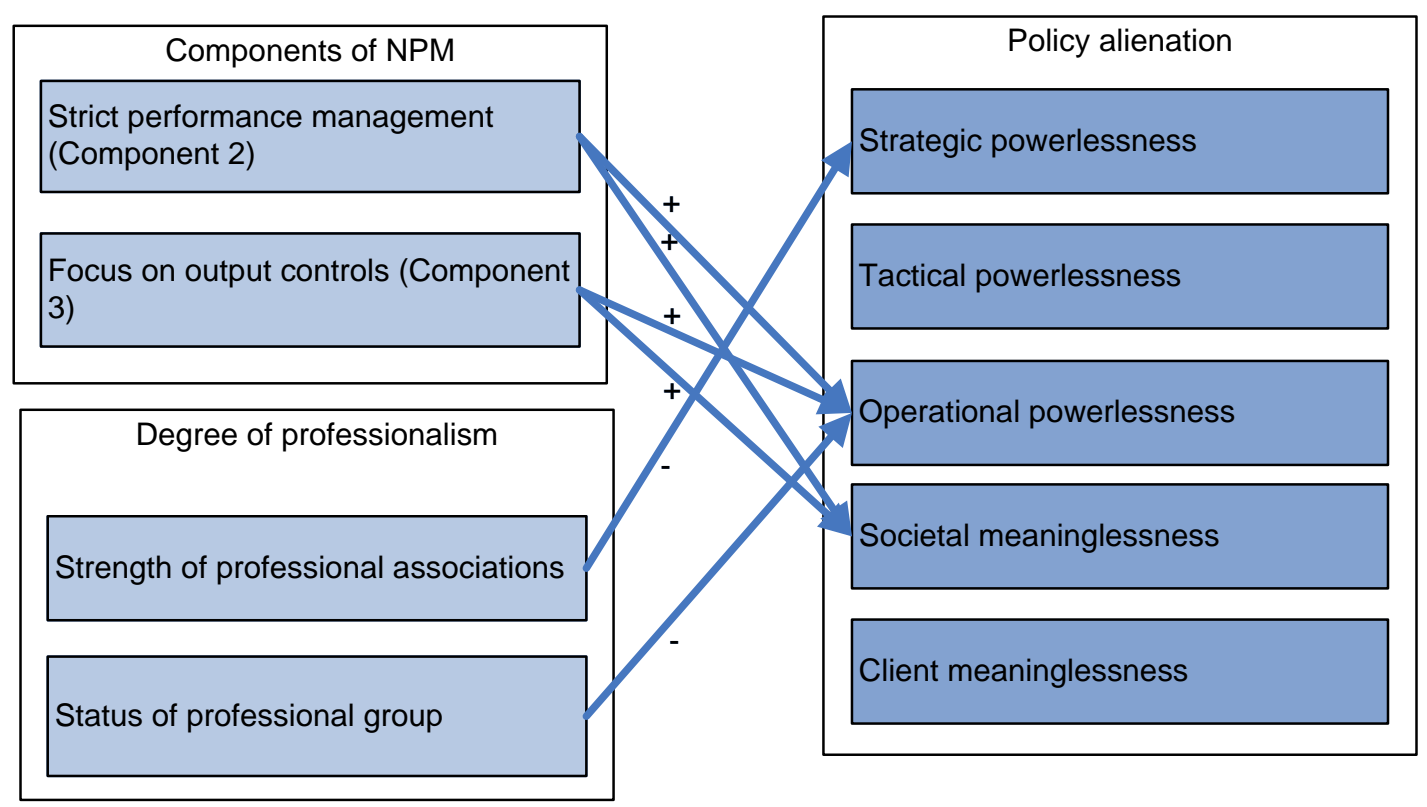

Figure 1 Theoretical framework: factors significantly influencing policy alienation dimensions 


\section{Comparative case study of insurance physicians and teachers}

\subsection{Method}

The main goal of this article is to examine which factors determine the experiences of public professionals with the policies they have to implement. We use the policy alienation framework to study these experiences. As a method, a qualitative comparative case study is used which allows us to study whether the factors that influence the degree of policy alienation are similar in different public domains.

The two cases, both in the Netherlands, discussed in this article are of insurance physicians, implementing the new so-called work disability decree, and of secondary school teachers implementing the 'Second Phase'. These were both substantial reforms which considerably affected the work of the professionals. For instance, Evers et al. (2002:229) called the Second Phase a 'fundamental and basic change, a transformation of culture'. Furthermore, the new work disability decree was clearly perceived as important by the professionals given the fact that about 240 physicians urged a strike against this new policy, and some simply decided to quit their job (NVVG 2005).

In order to ensure valid insights, we have triangulated our data (Yin, 2003:98). Firstly, we conducted extensive document analysis, as shown in Table 3. Secondly, semi-structured interviews with individual insurance physicians and teachers were held: seven with insurance physicians and five with individual teachers. These interviews were recorded and, following Mergenthaler and Stinson's guidelines for transcribing (1992:129-130, cited in McLellan et al., 2003), subsequently transcribed. Thirdly, we held large group discussions with a total of 35 professionals (two with insurance physicians (ten per group) and one with teachers (fifteen teachers)). Fourthly, we checked the validity of our reconstruction by discussing the results with members of the executive boards of the main professional associations - two for the physicians and two for the teachers. 
Table 3 Documents reviewed in comparative case study of physicians and teachers

\begin{tabular}{|c|c|c|}
\hline $\begin{array}{l}\text { Type of } \\
\text { document }\end{array}$ & Insurance physicians & Secondary school teachers \\
\hline $\begin{array}{l}\text { Empirical } \\
\text { academic books } \\
\text { and articles }\end{array}$ & $\begin{array}{l}\text { Berendsen (2007) } \\
\text { Deursen, Van der Burg \& Veldhuis } \\
\text { (2007) } \\
\text { Hartman \& Boerdam (2004) } \\
\text { Van der Burg \& Deursen (2008) } \\
\text { Van der Hart \& Moekoet (2003) }\end{array}$ & $\begin{array}{l}\text { Hemmer (2007) } \\
\text { Kips (2003) } \\
\text { Prick (2006) } \\
\text { Van der Werf (2005) } \\
\text { Van Veen (2003) }\end{array}$ \\
\hline $\begin{array}{l}\text { Newspaper } \\
\text { articles }\end{array}$ & $\begin{array}{l}\text { NRC }(2003,2005 a ; 2005 b ; 2005 c) \\
\text { Volkskrant (2005) }\end{array}$ & $\begin{array}{l}\text { NRC (2007a; 2007b; 2007c; 2007d) } \\
\text { Tromp (2003) } \\
\text { Volkskrant (2006) } \\
\text { Wolzak (1999) }\end{array}$ \\
\hline $\begin{array}{l}\text { Professional } \\
\text { reports, } \\
\text { magazines, } \\
\text { websites, and } \\
\text { broadcasts }\end{array}$ & $\begin{array}{l}\text { Hagoort (2004a; 2004b) } \\
\text { Kennedy (2005) } \\
\text { Komduur \& Egas (2006) } \\
\text { Kuik (2007) } \\
\text { LVA (2006) } \\
\text { NVVG (2005) } \\
\text { Senger (2006) } \\
\text { UWV (2003; 2005) } \\
\text { WAOCafé (2005a; 2005b; 2006a; } \\
\text { 2006b) } \\
\text { Zembla (2007) }\end{array}$ & $\begin{array}{l}\text { Kerkhoff-Meeuwis \& Vree (1998) } \\
\text { Nierop (2004) } \\
\text { Traas (2005) } \\
\text { Verbrugge \& Verbrugge-Breeuwsma } \\
\text { (2006) }\end{array}$ \\
\hline $\begin{array}{l}\text { Official policy } \\
\text { documents }\end{array}$ & $\begin{array}{l}\text { Ministry of Social Affairs and } \\
\text { Employment }(2004 ; 2005) \\
\text { Staatsblad (2004) }\end{array}$ & $\begin{array}{l}\text { Advisory Body on Second Phase } \\
\text { (2005) } \\
\text { Commission Education Reforms } \\
\text { (2008b) } \\
\text { Commission Education Reforms: } \\
\text { Interviews (2008a) } \\
\text { Kirschner \& Prins (2008) } \\
\text { Ministry of Education, Culture and } \\
\text { Science (2007) }\end{array}$ \\
\hline
\end{tabular}




\subsection{Background to the policies}

Work disability decree

In 2004, the Dutch government drafted new, stricter, rules regarding welfare benefits for citizens with work disabilities. The so-called adjusted assessment decree (ASB), implemented in October 2004, changed the insurance conditions for people already receiving work disability benefits. One of its aims was a substantial reduction in costs (SZW, 2005). The ASB is implemented through programs run by the Dutch Institute for Employees' Insurance (UWV), a semi-autonomous agency of the Ministry of Social Affairs and Employment. Within the UWV, insurance physicians are involved in implementing the ASB. They 'provide social-medical evaluations with respect to the legislation concerning sick leave and employee disability' (Berendsen, 2007:225).

\section{Second Phase}

In 1998, the Second Phase was implemented in the upper levels of the Dutch secondary school system. The Second Phase consisted of three elements (Van Veen, 2003:87):

1. The implementation of a 'constructivist' view on teaching and learning, called the Study House

2. The use of student study profiles, alongside new subjects

3. Greater autonomy for schools

The first element needs explanation as it amounted to a totally different view of the educational process. Most teachers had undergone 'behavioristic' training, which emphasizes the process of knowledge transmission and the expert role of the teacher. In contrast, the 'constructivist' view concentrates on the process of learning and the role of the student. Learning is assumed an active process of construction, and knowledge is the accumulation of information, as opposed to passive assimilation. The practical implications include fewer 'traditional classes' in which one teacher explains material to thirty students at once. Instead, the students have to learn the material more independently and in small groups, with the teacher acting as a facilitator of this process. In the following sections, we will discuss which factors influenced the policy alienation experienced by these two professional groups. 


\subsection{Policy powerlessness}

Powerlessness refers to the influence (or rather lack of) that public professionals have in shaping the policy program at various policy levels. Have insurance physicians and teachers experienced powerlessness and, if so, which factors influenced this?

\section{Influence at the strategic level}

With respect to powerlessness at the strategic level, we found hardly any evidence that the insurance physicians were able to influence the shaping of the policy. To do so, it would have been necessary to mobilize their professional associations and, although they tried, this did not happen (UWV, 2005:4). The main professional associations for the physicians, the NVVG and the UWVA, did not become involved in the political debate concerning the drafting of the new rules. As a result, many physicians became frustrated with the lack of influence of their professional associations in shaping the ASB, and this contributed to feelings of powerlessness.

The strategic powerlessness of teachers also seems to have been high during the discussion about the Second Phase. Teachers felt that the implementation was done in a top-down way, without consulting them (NRC, 2007a; Prick, 2006). The feelings as expressed by the interviewed teachers supported this. One stated that: 'What irritated me enormously was that the Second Phase was presented like: Guys, this is it, this in an important improvement for education. In my view, the knowledge and experience of teachers were not taken into account.' In general, if teachers want to influence the shaping of a policy, they have to do so through their associations and labor unions. However, the professional teacher associations are often based on a subject (such as history or mathematics) and in this instance they did not have a lot of influence, largely due to a lack of collaboration (Parliamentary Commission Education Reforms, 2008a:61, 69, 106). The labor unions representing the teachers also did not have much influence over the shaping of the Second Phase (Parliamentary Commission Education Reforms, 2008b:52). This lack of influence by both the professional associations and labor unions gave the teachers a sense of strategic powerlessness. This problem was acknowledged by a board member of one of the main professional associations. He stated that it was indeed true that the professional associations are increasingly unable to influence the political debate, to an extent because of the diminishing number of members. Further, aspects peculiar to this case also decreased the power of teachers to influence the policy. Here, one can include the development of a steering committee, headed by the Secretary of State, with no members from the professional associations, and the continuous stressing of the 'political primacy' by the Minister of Education. 
Influence at the tactical level

Tactical powerlessness refers to the perceived influence of professionals on decisions concerning the way a policy is implemented within their organization.

For the physicians, the reorganization that created the UWV was a factor that negatively affected their position as professionals since they could no longer effectively influence decisions concerning the way policy was implemented. The UWV was established in 2002, through a merger of six organizations that implemented a range of social security programs, in order to create a 'lean' and more integrated organization. In this merger, we can clearly recognize elements of NPM as the relationship between the newly formed UWV and the Ministry was based on a contractual form of governance in which results and costs play an important role. This results orientation is a concretization of the third NPM component - emphasis on output controls. Further, the focus on cost reduction, through downsizing, resembles the seventh component - stressing greater discipline in resource use.

Following this reorganization, professionals within the UWV are in a weak position since the organization has become increasingly hierarchical. An interviewed physician stated:

'We could not influence the policy very much. That is clear. The UWV is a top-down administrative organization focused on administrative processes. The professionals re-examining the clients are not the priority of the UWV. We were not consulted about the implementation conditions regarding the ASB.'

It seems that the degree of hierarchy within the organization was also a relevant factor for the teachers. However, whereas physicians felt they operated in a very hierarchical organization, many teachers experienced a more egalitarian structure within their organization. As one teacher put it: 'I believe that the position of the teacher is very strong [in our school]. If you are a school manager you know that it will not work if you coerce teachers to do something they do not believe in.' Consequently, in many schools, teachers were in a strong position to influence the way the Second Phase was concretized in their schools. As such, many perceived themselves to have influenced the way the Second Phase (in particular, the Study House) was enacted in their schools (Kips, 2003:48). Kips found, based on a survey of 142 teachers, that $45 \%$ agreed with the statement 'I have enough opportunities to influence the way the Study House was implemented in my school', against $28 \%$ who disagreed (rest neutral). 
However, in some schools, managers were the dominant party in implementing the Second Phase. Prick (2006:119) states that, in these schools, 'school management dictates how the Study House has to be modeled', and that this resulted in a higher degree of tactical powerlessness experienced by teachers. This dominance of management over professionals in these schools can also be seen as an illustration of the NPM characteristic that stresses 'private sector styles of management practice'; a move away from the public service ethic and professional values (Hood, 1991:5).

\section{Influence at the operational level}

At the operational level, many physicians perceived that their level of discretion, following the introduction of the ASB, had decreased: 'physicians had the feeling that they had less influence on their job performance and could use their own professional standards less' (Kammer, 2005). Conversely, a number of physicians stated that they still had considerable discretion, but that they had to provide a more thorough argument for their decisions to their superior, and that this took up more time. As one physician put it during an interview, he could still make decisions 'in all freedom'. Nevertheless, based on a survey by De Boer and Steenbeek (2005), we conclude that, in general, physicians experienced a somewhat lower level of discretion.

Two factors seem relevant for the discretion available to physicians. Firstly, the rules in the ASB - the policy content - put pressure on the professionals. The new rules were stricter and left less room for physicians to deviate from the policy program. Secondly, aspects of NPM were an influence on the discretion open to physicians. The UWV had to implement the ASB and, in a short period, more than 325,000 people had to be re-examined. To achieve this, the UWV focused primarily on the number of re-examinations completed, setting strict performance criteria and focusing on output controls. These two NPM components curtailed professional autonomy. Extensive performance management often involves strict internal instructions and managers can feel increasing pressure to produce results. These developments made it harder for physicians to use their own discretion (Berendsen, 2007; De Boer \& Steenbeek, 2005).

Many of the interviewed teachers similarly stated that their discretion had decreased. The rules in the Second Phase - the policy content - were also influential here. According to many teachers, the new rules substantially reduced their discretion. Kips (2003:54) notes that $75 \%$ of the teachers affected by the Second Phase agreed with the statement: 'With the introduction of the Second Phase, it became more difficult to deviate from the official program'. This was to an extent due to the intensive controlling mechanisms imposed by the national schools inspectorate, which stressed accountability and results, in line with NPMdoctrines. A second factor was the way management introduced the Study House concept 
into schools. The idea of the Study House was that students would be able to learn more independently. For students to be able to do this, management coerced teachers into constructing a schedule covering the course material before the start of the school year. Subsequently, the teachers were somewhat bound by this schedule, making it more difficult to exercise later discretion.

When we compare the two cases, it seems that the discretion of the teachers declined somewhat more than that of the physicians. The physicians' discretion in their core task - providing social-medical evaluations - did not change substantially (Bannink et al., 2006). As one interviewed physician stated:

'We could not influence the organizational implementation of the ASB very much [high tactical powerlessness]. The UWV had made clear arrangements with the politicians. What we could state was that we needed our professional discretion in the execution of the ASB. We found a clear compromise on this issue.'

For the teachers, their discretion over their work content did change significantly. This was partly due to the contents of the policy. It was also related to the fact that the professional status of teachers is much weaker than that of physicians. An indication that this is recognized is that professional associations of teachers are now trying to address this issue by developing a 'professional statute' in which one of the central concepts is professional autonomy. When discussing this subject with a board member of a teachers association, he stated 'that's why we are developing a professional statute, we would like to reach a situation where teachers can clearly state: I am the expert'.

\subsection{Policy meaninglessness}

Here, meaninglessness is seen in terms of the professionals' perceptions regarding the policy's contribution to a larger purpose. This can be on the societal and/or the client level.

\section{Meaninglessness at the societal level}

Do physicians see the policy goals of the ASB as meaningless? In the ASB, the official goal is to increase the participation in work of people suffering from disabilities by looking at a person's potential rather than at their limitations (SZW, 2005). Two arguments stressed in justifying this are, firstly, that it is nearly always healthier for people with physical or psychological problems to be active and, secondly, that Dutch social security has become too expensive.

In the eyes of many, the economic goal of the ASB seems to be the more important. As one physician put it: 'I see it more as a cost-saving policy than as a method to get people 
in work' (WAOcafé, 2006a). This suggests that, in the implementation of the ASB, NPMbased considerations (cost reductions and efficiency gains) dominate in the trading off of values, leading to a shift in value orientation. This was not welcomed by most physicians, increasing their sense of societal meaninglessness (De Boer \& Steenbeek, 2005; WAOcafé, 2006a).

A second factor contributing to societal meaninglessness, as witnessed by our respondents, was the number of policy changes regarding work disability. Between 2002 and 2006, major policy changes included the 'Gatekeeper Improvement Act', the ASB, and a new law on work and income. Such a situation contributed to feelings of societal meaninglessness for some physicians. The following comment from an interviewed physician illustrates this:

'Lately there have been so many changes: first the adjustments to the ASB, now the law regarding work and income. It happens all the time. I do not feel connected with politicians. Often they propose things which are not well thought out, but which have to be implemented right away.'

Finally, we should note that there was one aspect of the ASB which many physicians did agree with, that almost everyone receiving a work disability benefit had to be re-examined. Many claimants who were re-examined had not been examined for years, and so it became possible to assess changes in their condition, as well as remedy any previous errors in judgment. Almost all our respondents welcomed this explicitly.

Unlike the physicians, many teachers did not experience a high societal meaninglessness. The official objectives of the Second Phase are (a) to increase the quality of education in secondary schools and (b) to improve the connection with higher education (Advisory Body on Second Phase, 2005:12). Naturally, almost all teachers saw these as laudable goals. Kips (2003:49) stated that only $10 \%$ disagreed with the goals of the policy. One teacher expressed his agreement as follows: 'The goal of the Second Phase as it was once formulated, to improve the connection with higher education, is excellent' (Parliamentary Commission Education Reforms, 2008a:632). On the other hand, NPM-based considerations were also present here according to some teachers. A number of them believed that efficiency was a hidden goal. As one interviewed teacher stated: 'I think that one important goal, which was not made very explicit, was that the Second Phase was a cheaper method. It is almost inevitable: fewer teachers would be needed as students had to work more independently.' 
As already seen, another factor that influences societal meaninglessness is the number of policy changes. For the teachers, as with the physicians above, this factor positively contributed to societal meaninglessness (NRC, 2007a; Parliamentary Commission Education Reforms, 2008b:648; Prick, 2006), although the interviewed teachers experienced this factor less prominently than the interviewed physicians.

\section{Meaninglessness at the client level}

The physicians experienced significant differences in the level of client meaninglessness. Of the 230,000 clients re-assessed, 90,000 saw their benefits stopped or reduced. One and a half years after re-examination, $52 \%$ of those deemed able to work had not found a job (Van der Burg \& Deursen, 2008:80). A number of physicians identified strongly with this unfortunate group. They felt that they had not helped them, thus experiencing a high degree of client meaninglessness (De Boer \& Steenbeek, 2005; LVA, 2006). As one commented (cited in Kammer \& Jorritsma, 2005): 'I cannot put my signature to a medical evaluation which inevitably results in cutting state assistance for the person [...] someone who has been unemployed for ten years, and is searching for a job again, that is impossible'.

However, not all shared this view. Several respondents stressed that, especially for younger claimants, it could be beneficial to decrease work-disability benefits. In their view, being labeled as work-disabled for a very long time was detrimental to a person's health. In this way, they identified more with the policy program and less with the immediate wishes and concerns of their clients.

Considering this, we can see that the professional orientation of the physicians influenced their experienced meaninglessness. Some of the interviewed physicians differentiated between so-called 'hard' and 'soft' physicians. Hard physicians believe that lowering a benefit can induce people to search for a job and, when they ultimately find one, this is beneficial for them. However, softer physicians do not believe that reducing a benefit will result in a client becoming more active. For them, it is ultimately harmful for their clients if their benefits, and hence income, are reduced. From this standpoint, professional orientation influences the experienced meaningfulness of the ASB policy.

The professional orientation of the teachers also seemed to influence their experienced client meaninglessness. Van Veen (2003:103) distinguishes between two types of teachers. On the one hand you have teachers who are 'student-oriented' and consider personal and moral development to be among the goals of education. On the other hand, there are 'content-oriented' teachers, who consider qualifications to be the overriding goal of education. Looking at the two types of teachers, the constructivist orientation of the Second Phase fits better with the student-oriented teachers. As a result, they experience the Second Phase as more meaningful for their students as it resulted in students having to work more 
independently (Kips, 2003:50-51; Van Veen, 2003:127). In many schools, management framed this as a reduction in the number of hours that teachers had to teach each class, which can be viewed as a performance increase. Many content-oriented teachers experienced this situation as detrimental for the students (Kips, 2003:54; Nierop, 2004:24; Parliamentary Commission Education Reforms, 2008b:139). An interviewed, contentoriented, teacher stated:

'I had the idea that, as I had so many classes with fewer hours per class, it became too much for me. Those students which are not very able and also not prepared to work hard, I think they were really the victims of it all.'

More student-centered teachers, however, felt that their implementation of the Second Phase was very meaningful (Van Veen, 2003:60). As one put it:

'Because of the Second Phase, I feel that I am better able to help the students. Before, it was only old-fashioned teaching. As such, you did not have that many opportunities to really help them. In this way, I think it is better now.'

\subsection{Summarizing the empirical analyses}

Our goal for the empirical research phase was to determine which factors influence the policy alienation experienced by insurance physicians and teachers. Our comparative case study provided us with a number of factors, and these are summarized in Figure 2. 


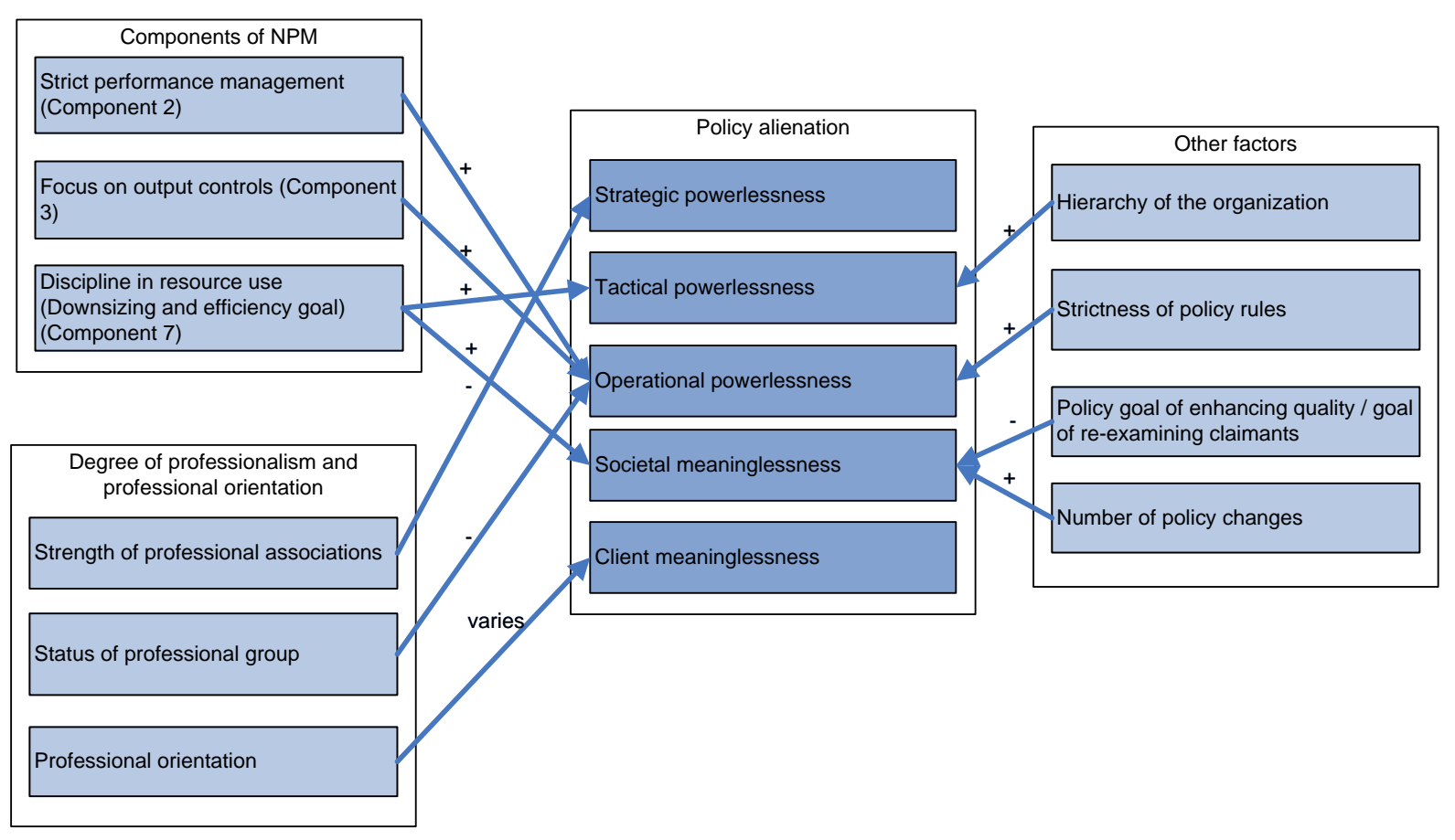

Figure 2 Key factors influencing the degree of policy alienation felt by teachers and physicians

We observed that numerous factors influenced the degree of policy alienation felt, and we clustered these variables into three categories: (1) New Public Management, (2) degree of professionalism and professional orientation and (3) other factors.

The degree of strategic powerlessness experienced was mainly determined by the strength of the professional associations. In both cases, the professional associations were not sufficiently strong to substantially influence the political debate. This led to a strong feeling of strategic powerlessness for both the insurance physicians and the teachers. Further, for the physicians, as a result of the constant downsizing, a focus on output controls, and the hierarchical nature of the UWV, they did not experience sufficient influence on the tactical level. Teachers, in contrast, experienced a more egalitarian structure, thereby experiencing significantly less tactical powerlessness, although this was not always the case. Operational powerlessness, linked to the discretion open to professionals, seemed to be influenced by a number of factors. For the physicians, we first saw that two components of New Public Management influenced their perceived discretion: strict performance measurement and a focus on output controls. However, their high status as physicians enabled them to still experience some discretion in their core task: providing social-medical evaluations. The discretion open to the teachers was, however, reduced somewhat more as (a) the strictness of the policy rules substantially reduced their discretion and (b) their professional status was not sufficiently legitimized for them to be able to counter the attack on their discretion. 
With respect to societal meaninglessness, we see that the NPM goal of cost reduction in the ASB led to a shift in value orientation, and one which was not welcomed by many physicians. The goal of re-assessing all those claiming the benefit seemed to be more appreciated. For the teachers, the Second Phase goal of enhancing educational quality was clearly appreciated by the teachers and, as a result, they experienced low societal meaninglessness. However, also here, some teachers noted that one goal was efficiency. Further, for both groups, it seems that the large number of policy changes increased the sense of societal meaninglessness somewhat. Looking at client meaninglessness, we see that the strength of this sub-dimension is particularly dependent on the professional orientation of the implementer. For instance, those teachers who were more student-oriented experienced less client meaninglessness in the case studied.

\section{Discussion and conclusions}

In contemporary public management literature, there is an intense ongoing debate concerning professionals in service delivery (Ackroyd et al., 2007; Currie et al., 2009; Emery \& Giauque, 2003; Exworthy \& Halford, 1998; Freidson, 2001; Hebson et al., 2003; Pratchett $\&$ Wingfield, 1996). As part of the fashion for neoliberal doctrines, policies have been introduced in recent decades which focus on economic values that can run against the values held by the professionals who implement the policies. In this article, using a policy alienation framework, we have examined the pressures professionals face when implementing public policies. Based on the theoretical framework and the empirical results, a number of conclusions can be drawn that contribute to the debate on public professionals in service delivery.

Firstly, we see that New Public Management is indeed a significant factor in shaping the experiences of professionals who have to implement public policies (see also Emery \& Giauque, 2003). However, there were also a number of factors affecting these experiences that were not related to NPM. Clearly, NPM was not the only factor that put pressure on professionals, a finding which contrasts with the views of some authors (for example, Peters \& Pouw, 2005). Our analysis shows that other forces are also at play, necessitating a broader view when examining pressured professionals. Policy implementation is embedded in national (for instance the strength of professional groups), organizational (such as the degree of hierarchy), and policy contexts (for instance the number of policy changes). This contextualized view on policies runs parallel to some of the findings of Ozga and Jones (2006) who discuss knowledge transfer in Scotland as a policy which is both 'travelling' (shaped by globalizing trends) and 'embedded' (mediated by local contextual factors). 
Looking especially at the degree of professionalism (an important factor rarely considered in the literature on policy implementation), we note that a first indicator of its likely influence is the strength of the professional associations. Professional associations can serve as advocates for their profession (see also Greenwood et al., 2002). In so doing, the strength of the professional associations will be influential in explaining the degree of pressure experienced by public professionals.

Further, the status of the professional group is important in explaining the pressures facing professionals. The physicians proved more capable than the teachers of maintaining discretion in their core task, and their professional status proved an important factor in this. Professionals with a relatively low status (such as teachers) seem to have greater difficulty in retaining discretion, and this leads to experiencing increased pressures. This is maybe also why 'semi-professionals', such as teachers, nurses, labor experts, and homecare workers, are experiencing increasing pressures: their professional status is insufficient to guard them against demands imposed by new policies (see also Hayes, 2001).

We also note that the professional orientation of the individual implementers strongly influences the pressures they experience. Not all professionals experience a policy in the same way. Here, the extent of the 'professional orientation - policy fit' seems to influence the pressures experienced by individual professionals in a similar way to the better known person-organization fit (Kristof, 1996). This could influence the success of a policy's implementation (van Veen et al., 2001:191). We suggest that this professional-policy fit could be a fruitful concept that could provide a structure for new research on professionals and policies.

This article also provides insights for practitioners. For instance, we have shown that policies with quality-enhancing goals are more readily accepted than policies with efficiency goals. Also, policymakers could choose to involve professional associations more intensively, or to loosen the rules in order to leave professionals some discretion in applying the rules on a case-by-case basis. Further, we found that introducing numerous policy changes increases the sense of societal meaninglessness, as professionals feel overwhelmed by the changes. This finding corresponds with findings in the business administration literature on 'change fatigue' (Judson, 1991). More in general, policymakers and managers can use aspects of the article (especially Figure 2) in considering which opportunities are available to increase the commitment (or lower the alienation) of public professionals implementing policies, so as to increase policy effectiveness.

We end this article by suggesting a number of directions for further research. First, the effects of policy alienation could be explored. For instance, does high policy alienation result in professionals becoming dissatisfied with their work or cynical concerning the new policies they have to implement? Second, the factors that determine policy alienation in 
different countries could be studied. It is not unreasonable to expect different relationships to exist in different countries, as there may be different ways of treating and perceiving professionals. Third, using an extended theoretical framework, the factors, the degree of policy alienation, and the effects could be studied more systematically, and in a quantifiable way, to explore the relative strengths of the various relationships. This could help policymakers design appropriate interventions to reduce the degree of policy alienation and so improve the policy implementation process.

\section{Literature}

Ackroyd, S., Kirkpatrick, I., \& Walker, R. M. (2007). Public management reform in the UK and its consequences for professional organization: A comparative analysis. Public Administration, 85(1), 9-26.

Ball, S. J. (2003). The teacher's soul and the terrors of permativity. Journal of Education Policy, 18(2), 215-228.

Bekkers, V. J. J. M., Edwards, A., Fenger, M., \& Dijkstra, G. (2007). Governance and the democratic deficit, assessing the legitimacy of governance practices. Aldershot: Ashgate.

Bottery, M. (1998). Professionals and policy: Management strategy in a competitive world. London: Routledge.

Bucher, R., \& Stelling, J. (1969). Characteristics of professional organizations. Journal of Health and Social Behavior, 10(1), 3-15.

Cameron, K. (1978). Measuring organizational effectiveness in institutions of higher education. Administrative Science Quarterly, 23(December), 604-632.

Chakravarthy, B. S. (1986). Measuring strategic performance. Strategic Management Journal, , 437-458.

Clarke, J., \& Newman, J. (1997). The managerial state: Power, politics and ideology in the remaking of social welfare. London: Sage.

Currie, G., Finn, R., \& Martin, G. (2009). Professional competition and modernizing the clinical workforce in the NHS. Work, Employment \& Society, 23(2), 267.

Duyvendak, J. W., Knijn, T., \& Kremer, M. (Eds.). (2006). Policy, people, and the new professional. de-professionalisation and re-professionalisation in care and welfare. Amsterdam: Amsterdam University Press.

Emery, Y., \& Giauque, D. (2003). Emergence of contradictory injunctions in swiss NPM projects. International Journal of Public Sector Management, 16(6), 468-481.

Eraut, M. (1994). Developing professional knowledge and competence. London: Routledge. 
Evers, W. J. G., Brouwers, A., \& Tomic, W. (2002). Burnout and self-efficacy: A study on teachers' beliefs when implementing an innovative educational system in the netherlands. British Journal of Educational Psychology, 72(2), 227-243.

Ewalt, J. A. G., \& Jennings, E. T. (2004). Administration, governance, and policy tools in welfare policy implementation. Public Administration Review, 64(4), 449-462.

Exworthy, M., \& Halford, S. (Eds.). (1998). Professionals and the new managerialism in the public sector. Maidenhead, UK: Open University Press.

Freidson, E. (2001). Professionalism: The third logic. Cambridge: Cambridge University Press.

Greenwood, R., Suddaby, R., \& Hinings, C. R. (2002). Theorizing change: The role of professional associations in the transformation of institutionalized fields. The Academy of Management Journal, 45(1), 58-80.

Harvey, D. (2007). A brief history of neoliberalism. Oxford: Oxford University Press.

Hayes, D. (2001). Professional status and an emerging culture of conformity amongst teachers in England. Education 3-13, 29(1), 43-49.

Hebson, G., Grimshaw, D., \& Marchington, M. (2003). PPPs and the changing public sector ethos: Case-study evidence from the health and local authority sectors. Work, Employment and Society, 17(3), 481-501.

Hill, M., \& Hupe, P. (2009). Implementing public policy (2nd ed.). Thousand Oaks: Sage. Holland, D. C., Nonini, D. M., Lutz, C., \& Bartlett, L. (2007). Local democracy under siege: Activism, public interests, and private politics. New York: NYU.

Hood, C. (1991). A public management for all seasons. Public Administration, 19(1), 3-19. Hood, C., \& Peters, G. (2004). The middle aging of new public management: Into the age of paradox? Journal of Public Administration Research and Theory, 14(3), 267-282.

Judson, A. S. (1991). Changing behavior in organization: Minimizing resistance to change. Cambridge, MA: Basil Blackwell.

Kaplan, R. S., \& Norton, D. P. (1992). The balanced scorecard-measures that drive performance. Harvard Business Review, 70(1), 71-79.

Kickert, W. J. M. (2010). Managing emergent and complex change: The case of dutch agencification. International Review of Administrative Sciences, 76(3), 489-515.

Kristof, A. L. (1996). Person-organization fit: An integrative review of its conceptualizations, measurement, and implications. Personnel Psychology, 49(1), 1-49.

Le Grand, J. (2007). The other invisible hand: Delivering public services through choice and competition. New Jersey: Princeton University Press.

Lewin, K. (1951). Field theory in social science New York: Harper.

Lipsky, M. (1980). Street-level bureaucracy. New York: Russell Sage Foundation. 
Marquand, D. I. (2004). Decline of the public. Cambridge: Polity Press.

May, P. J., \& Winter, S. C. (2009). Politicians, managers, and street-level bureaucrats: Influences on policy implementation. Journal of Public Administration Research and Theory, 19(3), 453.

McLellan, E., MacQueen, K. M., \& Neidig, J. L. (2003). Beyond the qualitative interview: Data preparation and transcription. Field Methods, 15(1), 63-84.

Neely, A. D. (Ed.). (2008). Business performance measurement: Unifying theories and integrating practice. Cambridge: Cambridge University Press.

Noordegraaf, M. (2007). From 'Pure' to 'Hybrid' professionalism: Present-day professionalism in ambiguous public domains. Administration \& Society, 39(6), 761785.

O'Toole, L. J. (2000). Research on policy implementation: Assessment and prospects. Journal of Public Administration Research and Theory, 10(2), 263-288.

Ozga, J., \& Jones, R. (2006). Travelling and embedded policy: The case of knowledge transfer. Journal of Education Policy, 21(1), 1.

Peters, J., \& Pouw, J. (2005). Intensieve menshouderij. hoe kwaliteit oplost in rationaliteit. Schiedam: Scriptum.

Pollitt, C. (2003). The essential public manager. Maidenhead: Open University Press.

Pollitt, C., \& Bouckaert, G. (2004). Public management reform. A comparative analysis. Oxford: Oxford University Press.

Power, M. (1997). The audit society: Rituals of verification. Oxford: Oxford University Press. Pratchett, L., \& Wingfield, M. (1996). Petty bureaucracy and woolly-minded liberalism? the changing ethos of local government officers. Public Administration, 74(4), 639-656.

Roberts, J. (2006). Limits to communities of practice. Journal of Management Studies, 43(3), 623-639.

Tummers, L. G. (2009). Policy alienation of public professionals: The development of a scale. Annual Work Conference Netherlands Institute of Government (NIG) (12-13 November), Leiden University: Leiden.

Tummers, L. G., Bekkers, V. J. J. M., \& Steijn, A. J. (2009). Policy alienation of public professionals: Application in a new public management context. Public Management Review, 11(5), 685-706.

Van Meter, D. S., \& Van Horn, C. E. (1975). The policy implementation process: A conceptual framework. Administration \& Society, 6(4), 445-488.

Yin, R. K. (2003). Case study research: Design and methods (3rd ed.). Thousand Oaks, CA: Sage. 


\section{References from document analysis}

Advisory Body on Second Phase. (2005). Zeven jaar tweede fase, een balans. Den Haag: Ando.

Bannink, D., Lettinga, B., \& Heyse, L. (2006). NPM, bureaucratisering en de invloed op de professie. B En $m, 33(3), 159-174$.

Berendsen, L. (2007). Bureaucratische drama's: Publieke managers in verhouding tot verzekeringsartsen. (Phd-thesis, Tilburg University).

De Boer, W., \& Steenbeek, R. (2005). Probleemsituaties en dilemma's in de verzekeringsgeneeskunde.NVVG.

Deursen, C. G. L., Van der Burg, C. L., \& Veldhuis, V. (2007). Herbeoordeeld.....en dan?. Leiden: Astri.

Hagoort, B. (2004a). Interview met elske ter veld. Aanrader, 1(1), 1-4.

Hagoort, B. (2004b). UWV-directeur: 'mening elske ter veld is achterhaald'. [Opinion chairman NVVA out-dated] Aanrader, 1(2), 1-4.

Hartman, H., \& Boerdam, A. (2004). Arbeidsongeschiktheidsuitkeringen 1987-2003. SociaalEconomische Trends, 4, 51-55.

Hemmer, W. (2007). Het onderwijs als laboratorium. Rijksuniversiteit Groningen).

Kammer, C. (2005, Nov. 3). De geus ziet nog steeds geen crisis bij UWV. NRC Handelsblad, pp. 3.

Kammer, C., \& Jorritsma, E. (2005, Nov. 5). Gefeliciteerd! U kunt aan het werk; keuringsartsen onder druk bij de herkeuring van WAO-ers. NRC Handelsblad, pp. 3.

Kennedy, R. (2005). Robots gevraagd voor medische keuringen. Tribune, 21(Jan.), 1-4.

Kerkhoff-Meeuwis, I., \& Vree, S. (1998). De achterkant van het studiehuis: Wegwijzer voor ouders en begeleiders van middelbare scholieren. Hilversum: Psychologisch instituut Hilversum.

Kips, M. (2003). Van taakoverdracht naar procesbegeleiding. Erasmus University Rotterdam).

Kirschner, P. A., \& Prins, F. J. (2008). Survey for parliamentary commission education reforms No. 31007). Utrecht: Utrecht University.

Komduur, J., \& Egas, C. (2006). Eenmalige herbeoordelingen; het verhaal achter de cijfers. Amsterdam: BPV\&W.

Kuik, A. (2007). De macht van het UWV. Klantenkrant, 51(Feb.), 8-9.

LVA. (2006). We zijn gedwongen strenger te keuren. Digitale Nieuwsbrief LVA, 44(December 2006), 2-6.

Mau, R. Y. (1992). The validity and devolution of a concept: Student alienation. Adolescence, 27(107), 731-741. 
Nierop, D. (2004). Geen tijd voor het studiehuis. Utrecht/Den Bosch: APS.

NRC. (2003, Sept. 13). Ik hoop dat ze in den haag van hun plannen afzien. NRC

Handelsblad, pp. 16.

NRC. (2005, May 30). Reorganisatie UWV. NRC Handelsblad,

NRC. (2007a, October 10). Havo 'voor dummies'; de geschiedenis van de tweede fase. NRC Handelsblad, pp. 10.

NRC. (2007b, October 2). 'Ik eis klassen van 22 leerlingen'. NRC Handelsblad, pp. 3.

NRC. (2007c, April 20). Kom niet aan de vakanties van leraren. NRC Handelsblad, pp. 3.

NRC. (2007d, December 5). Onderwijsvernieuwingen, het repeterende verhaal. NRC Handelsblad, pp. 2.

OC\&W. (2007). Regelgeving voor de vernieuwde tweede fase

Palm, I., Leffers, F., Emons, T., Van Egmond, V., \& Zeegers, S. (2008). De GGz ontwricht: Een praktijkonderzoek naar de gevolgen van het nieuwe zorgstelsel in de geestelijke gezondheidszorg. Den Haag: SP.

Parliamentary Commission Education Reforms. (2008a). Interviews tijd voor onderwijs.31007(10)

Parliamentary Commission Education Reforms. (2008b). Tijd voor onderwijs.31007(6)

Prick, L. (2006). Drammen, dreigen, draaien. Alpen aan den Rijn: Haasbeek.

Sengers, L. (2006, Nov. 3). Het wankele WAO-succes. Intermediar,

Staatsblad. (2004). Besluit van 18 augustus 2004 tot wijziging van het schattingsbesluit arbeidsongeschiktheidswetten. Ministry of Social Affairs:

SZW. (2004). Brief van minister de geus over het deskundigenoordeel huisvestingskosten UWV

SZW. (2005). Nieuwe wet werk en inkomen naar arbeidsvermogen per 1 januari 2006 ingevoerd [new Law Work and Income, 2006] SZW.

Traas, J. C. (2005). Onderwijskundigen, waarheidsliefde en de tweede fase. In M. L. A. Rietdijk (Ed.), Steeds minder leren (pp. 57-68). Utrecht: Uitgeverij ljzer.

Tromp, B. (2003, September 4). Tempo van vernieuwing onderwijs haast niet te volgen. Het Parool, pp. 17.

UWV. (2003). Claimbeoordelings- en borgingssysteem (CBBS). Amsterdam: UWV.

UWV. (2005). Het woord is aan de professionals. Amsterdam: UWV.

Van der Burg, C. L., \& Deursen, C. G. L. (2008). Eindrapportage herbeoordeeld...en dan?. Leiden: Astri.

Van der Hart, J., \& Moekoet, S. (2003). Een beschrijvend onderzoek over de ervaringen van verzekeringsartsen en arbeidsdeskundigen met het CBBS. (Thesis, NSOH).

Van der Werf, M. P. C. (2005). Leren in het studiehuis: Consumeren, construeren of engageren? (oration). Groningen: Rijksuniversiteit Groningen. 
Van Veen, K. (2003). Teacher's emotions in a context of reforms. Nijmegen: Radboud University.

van Veen, K., Sleegers, P., Bergen, T., \& Klaassen, C. (2001). Professional orientations of secondary school teachers towards their work. Teaching and Teacher Education, 17(2), 175-194.

Verbrugge, A., \& Verbrugge-Breeuwsma, M. (2006). Manifest: Beter onderwijs nederland. Retrieved November, 2, 2008, from http://beteronderwijsnederland.net/?q=node/231

Volkskrant. (2005, Nov. 5). Het wrange succes van de WAO-herkeuringen. De Volkskrant, pp. 7.

Volkskrant. (2006, July 1). Enquête: Leraren willen meer zeggenschap. De Volkskrant, pp. 2.

WAOcafé. (2005a). Fred van duijn. Retrieved januari, 2009, from http://www.waocafe.nl/depraktijk/interviews_het_veld/i1070.html

WAOcafé. (2005b). Interview UWV-arts. Retrieved januari, 2009, from http://www.waocafe.nl/depraktijk/interviews_het_veld/i1071.html

WAOcafé. (2006a). Gesprek verzekeringsarts. Retrieved januari, 2009, from http://www.waocafe.nl/depraktijk/interviews_het_veld/i1944.html

WAOcafé. (2006b). Voorzitter NVVA: Wij zijn stil geweest. Retrieved januari, 2009, from http://www.waocafe.nl/depraktijk/interviews_het_veld/i2731.html

Wolzak, I. (1999, December 5). De ideale leerling zonder jeugdpuistjes bestaat niet. Trouw, pp. 25.

Zembla. (2007). Wonderdokters van de WAO (television broadcast). The Netherlands: 